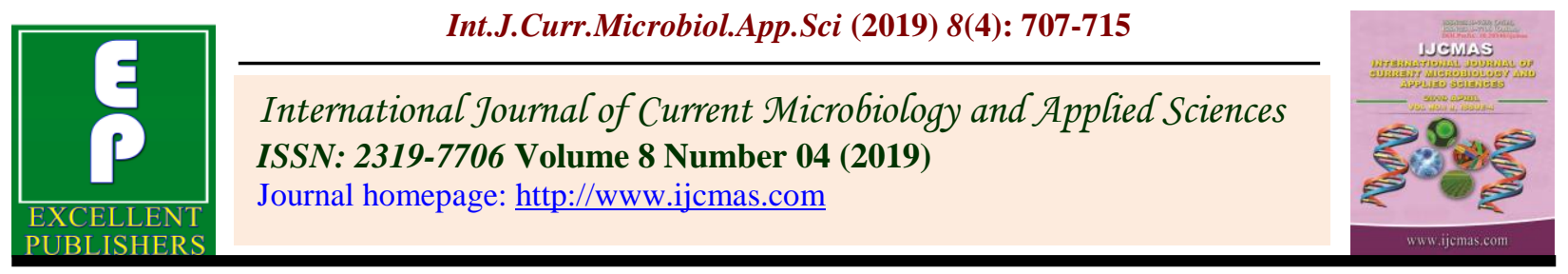

Original Research Article

https://doi.org/10.20546/ijcmas.2019.804.076

\title{
Analyzing Different Spacing and Fertilizer Applications Interaction Effect on Growth, Flowering and Yield of Gladiolus (Gladiolus grandiflorus L.)
}

\author{
Santosh Kumar Beck ${ }^{1}$, Manoj Kumar Beck ${ }^{2^{*}}$ and Premanshu Agrawal ${ }^{1}$ \\ ${ }^{1}$ Sam Higginbottom Institute of Agriculture, Technology \& Sciences, Allahabad (U.P.), India \\ ${ }^{2}$ Department of Agrometeorology, IGKV, Raipur (CG), India \\ *Corresponding author
}

\begin{tabular}{|c|}
\hline Keywords \\
\hline $\begin{array}{l}\text { Gladiolus, Spacing } \\
\text { Organic manures, } \\
\text { Inorganic Fertilizer }\end{array}$ \\
\hline Article Info \\
\hline $\begin{array}{l}\text { Accepted: } \\
07 \text { March } 2019 \\
\text { Available Online: } \\
10 \text { April } 2019\end{array}$ \\
\hline
\end{tabular}

A B S T R A C T

An experiment was conducted in factorial Randomized Block Design (FRBD) with three replications and twelve treatments. The allocation of treatments to the individual plots was done using random numbers in each replication. The corms were planted on 17 Oct. 2015. The treatments consisted of three various spacing i.e., $30 \mathrm{~cm} \times 30 \mathrm{~cm}, 30 \mathrm{~cm} \times 15 \mathrm{~cm}$ and 40 x $15 \mathrm{~cm}$ and four combination of fertilizers RDF 200:200:200, NPK 75\% + FYM 25\%, NPK $75 \%+$ GM25\%, NPK 75\% + VC25\%. The treatment $\mathrm{T}_{12}: 30 \times 15 \mathrm{~cm}^{2}+\mathrm{NPK} 75 \%+$ VC25\% performed higher in number of leaves per plant, height of the plant $(\mathrm{cm})$, crop growth rate (CGR), days to spike emergence, length of the spike, number of florets per spikes, vase life of cut spikes (days),days to opening of first florets, longevity of first florets (days). whereas the earliest 50\% sprouting, number of sprouts per mother corm, the yield of corms per hectare, number of corms per plant, number of spike per plant and spike yield per hectare recorded highest in Treatment $\mathrm{T}_{8}: 30 \mathrm{~cm} \times 15 \mathrm{~cm}+\mathrm{NPK} 75 \%+\mathrm{VC} 25 \%$ and the treatment $\mathrm{T}_{11}: 40 \times 15 \mathrm{~cm}^{2}+\mathrm{NPK} 75 \%+\mathrm{GM} 25 \%$ performed best in Diameter of corms $(\mathrm{cm})$ and Weight of corms $(\mathrm{g})$. Treatment $\mathrm{T}_{10}: 40 \times 15 \mathrm{~cm}^{2}+75 \% \mathrm{NPK}+25 \% \mathrm{FYM}$ i.e. observed highest in width of leaf $(\mathrm{cm})$. The cost and return associated with the cultivation of gladiolus in the present investigation clearly indicated that the net return Rs.14,28,591/ha and benefit cost ratio (2.89: 1) were highest in treatment $\mathrm{T}_{8}$.

\section{Introduction}

Gladiolus name is derived from the Latin word 'gladius' means sword because of leaves being sword-like in appearance. Gladiolus (Gladiolus grandiflorus) is said to be the "Queen of bulbous plant", because the gladiolus is top in the list of its beauty, glamour, keeping quality, long range of colour like white, crimson, pink, orange, salmon, red, purple cream and rose etc. shades and shapes. Gladiolus is one of the most popular flowering plants, because of its colourful and attractive succession from the bottom. They are available in an extensive array of colours. They produce flowers in almost every shade and may be bi-or tricoloured. The flowers open first at the base of the spike with the older ones dying as the new ones unfurl. They may be frilly, ruffled, or plain. Plants are generally of two types (1) Having large florets (2) Having miniature or 
butterfly type flowers. Plant is straight and leaves are also straight, spike stand straight from the base. Beyond the limit or higher rate of nitrogen delayed the time of flowering and increased the spike length, weight and size of corms. The higher rate of phosphorus and potassium tended to improve the flower quality.

\section{Materials and Methods}

Field preparation was done by ploughing the field with mould board plough once, followed by levelling and weeding manually. Then the field was divided into three blocks spaced at one meter distance. Each block was further sub-divided into twelve sub-plots at a distance of $0.5 \mathrm{~m}$. The given amount of FYM, Vermicompost and Goat manure was applied in each sub plot treatment wise and then and mixed properly. The usual method of propagation of gladiolus is through corms and cormels. Healthy corms size ranged between $3 \mathrm{~cm}$ to $5 \mathrm{~cm}$ were planted after treating with Bavistin@ $1 \mathrm{gm} / \mathrm{kg}$ corm. FYM, Vermicompost and Goat manure were given as basal in the given plots treatment wise. Recommended fertilizer of dozes Nitrogen $(\mathrm{N}=0.130 \mathrm{gm} / \mathrm{plot})$ phosphorous $(\mathrm{P}=0.375 \mathrm{gm} /$ plot) and potassium ( $\mathrm{K}=0.99 \mathrm{gm} / \mathrm{plot})$ were given during course of experiment. Full doses of potassium and phosphorous were given as basal application at the time of planting and nitrogen was given in three split doses i.e. one forth as basal and remaining three fourth in two equal and split dozes i.e. one at 3 and another at 6 leaf stages. Before planting of corms in the soil, a soil sample was collected from experimental field and analyzed for physical-chemical characteristics. Gladiolus may be grown on wide range of soils. Sandy loam soil is suitable for good growth and flowering. The most suitable $\mathrm{pH}$ range is 6-7. The soil should be well drained and free from soil borne disease. It is grown in open fields, beds, pots and a border etc. The soil of experimental field was sandy loam in texture and slightly alkaline in reaction. The soil was low in organic carbon (0.45), available nitrogen low (155.40), available phosphorus medium (14.76), and available potassium medium (139.82).

\section{Results and Discussion}

The data presented in Table 1 envisaged that the fifty percent of sprouting the minimum number of days (5.33) was taken by treatment $\mathrm{T}_{8}\left(30 \times 15 \mathrm{~cm}^{2}+75 \% \mathrm{NPK}+25 \%\right.$ Vermicompost), whereas the maximum number of days (6.46) for 50 percentages sprouting was recorded in the treatment $\mathrm{T}_{1}(30$ X $\left.30 \mathrm{~cm}^{2}+200: 200: 200 \mathrm{~kg} \mathrm{NPK}\right)$. The earliness in sprouting may be due to the application of chemical fertilizer in combination with FYM which promotes or induces early sprouting of corm. This result is confirmed with the findings of Bisen and Barholia (1990) and Singh (1998) in potato and gladiolus respectively.

The data presented in Table 1 envisaged that the maximum number of sprouts per mother corm (1.46) was found in the treatment $\mathrm{T}_{8}$ (30 X $15 \mathrm{~cm}^{2}+75 \% \mathrm{NPK}+25 \%$ Vermicompost). The minimum number of sprouts per mother corm (1.00) was recorded in treatment $\mathrm{T}_{1}$ (30 X $\left.30 \mathrm{~cm}^{2}+200: 200: 200 \mathrm{~kg} \mathrm{NPK}\right)$. The superiority of treatment $\mathrm{T}_{8}$ over the rest of the treatments might be due to availability of optimum amount of nutrient from inorganic fertilizer in combination with Vermicopost. This result is in close conformity with the findings of Singh and Singh (1971).

The data presented in Table 1 envisaged that the number of leaves per plant was counted at 30, 60 and 90 days after planting. The maximum number of leaves was observed (10.40) in treatment $\mathrm{T}_{12}\left(40 \times 15 \mathrm{~cm}^{2}+\mathrm{NPK}\right.$ $75 \%+$ Vermicompost 25\%). Minimum number of leaves per plant was observed 
(6.86) in treatment $\mathrm{T}_{1}\left(30 \mathrm{X} 30 \mathrm{~cm}^{2}+\right.$ 200:200:200 kg NPK). This might be due to continues availability of essential nutrient to the crop by the application of inorganic fertilizer in combination with organic Vermicompost. These observations followed the results of Ahmed et al., (2004).

The data presented in Table 1 envisaged that the data on height of the plant was recorded at 30, 60 and 90 days after planting. The maximum height of the plant was observed $(124.13 \mathrm{~cm})$ in treatment $\mathrm{T}_{12}\left(40 \times 15 \mathrm{~cm}^{2}+\right.$ NPK $75 \%$ + Vermicompost 25\%) and it was significantly superior over all of the treatments. Minimum height of the plant was noted $(117.66 \mathrm{~cm})$ in treatment $\mathrm{T}_{1}(30 \mathrm{X} 30$ $\left.\mathrm{cm}^{2}+200: 200: 200 \mathrm{~kg} \mathrm{NPK}\right)$. The maximum height of plant under the treatment $T_{12}$ might be associated with the availability of optimum nutrient to the plant throughout the growth period by the application of inorganic fertilizer in combination with Vermicompost. This is in accordance with the findings of Widjajanto and Widodo (1982).

The data presented in Table 1 envisaged that the maximum leaf width (3.69) was obtained in treatment $\mathrm{T}_{10}\left(40 \mathrm{X} 15 \mathrm{~cm}^{2}+\mathrm{NPK} 75 \%+\right.$ FYM 25\%) and the treatment $\mathrm{T}_{1}\left(30 \times 30 \mathrm{~cm}^{2}\right.$ $+200: 200: 200 \mathrm{~kg}$ NPK) recorded the minimum leaf width (3.05).

Similar result was recorded by Shankar (2001). He observed that the leaf breadth of gladiolus was maximum in the treatment NPK@ 40:20:20g/m2, Singh and Bijimol (2000) (Tuberose).

The data presented in Table 2 envisaged that the days to opening of first florets was recorded minimum in treatment $\mathrm{T}_{12}(40 \times 15$ $\mathrm{cm}^{2}+$ NPK $75 \%+$ Vermicompost $25 \%$ ) (16.00) and minimum number of florets per spikes was recorded in the treatment $\mathrm{T}_{1}(30 \mathrm{X}$ $\left.30 \mathrm{~cm}^{2}+200: 200: 200 \mathrm{~kg} \mathrm{NPK}\right)$ (11.02).
Findings are in conformity with the findings of Singh and Bijimol (2000).

The data presented in Table 2 envisaged that the maximum longevity of first florets in $\mathrm{Al}_{2}$ $\left(\mathrm{So}_{4}\right)_{2} 200 \mathrm{ppm}$ (5.74) was obtained in the treatment $\mathrm{T}_{12}\left(40 \times 15 \mathrm{~cm}^{2}+\mathrm{NPK} 75 \%+\right.$ Vermicompost $25 \%$ ) whereas the minimum longevity was found in the treatment $\mathrm{T}_{1}(30 \mathrm{X}$ $30 \mathrm{~cm}^{2}+200: 200: 200 \mathrm{~kg} \mathrm{NPK}$ ) (4.11 days). It may be due to the exogenous supply of $\mathrm{Al}_{2}\left(\mathrm{SO}_{4}\right)_{2}$ \& Sucrose which replaced the depleted endogenous carbohydrate, utilized during the postharvest life of lower and thereby enhanced vase life Kumar (2005).

The data presented in Table 2 envisaged that the minimum number of days to spike emergence 64.40 days was taken by the treatment $\mathrm{T}_{12}\left(40 \times 15 \mathrm{~cm}^{2}+\mathrm{NPK} 75 \%+\right.$ Vermicompost 25\%). The maximum number of days to spike emergence 77.46 days. Was taken by the treatment $\mathrm{T}_{1}\left(30 \mathrm{X} 30 \mathrm{~cm}^{2}+\right.$ 200:200:200 kg NPK) The earliness in spike emergence by the application of Vermicompost in combination of inorganic fertilizer may be due to optimum availability of nutrients to the plant due to which plant completed their vegetative growth soon resulting in early spike emergence. These results are in close conformity with the findings of Ahmed et al., (2004). They observed that the treatment which was comprised of $20 \mathrm{~g}$ urea $/ \mathrm{m} 2+40 \mathrm{~g}$ (DAP) $/ \mathrm{m} 2$ $+4 \mathrm{~kg} \mathrm{FYM} / \mathrm{m} 2$ taken minimum number of days for emergence flower bud in Dahlia.

The data presented in Table 2 envisaged that the maximum length of spike $(101.35 \mathrm{~cm})$ was recorded in the treatment $\mathrm{T}_{12}$. The minimum length of the spike $60.82 \mathrm{~cm}$.was obtained in treatment $\mathrm{T}_{1}\left(30 \times 30 \mathrm{~cm}^{2}+\right.$ 200:200:200 kg NPK) The maximum length of the spike in treatment $T_{12}$ may be due to the availability of sufficient amount of nitrogen in different phases of growth and 
development of plants which promotes the length of the spike. Similar result was recorded by Gupta et al., (2008). They reported that the maximum length of the spike in gladiolus was obtained by applying Vermicompost@2.5kg/m².

The data presented in Table 2 envisaged that the maximum number of florets per spike 16.00 was counted in the treatment $\mathrm{T}_{12}(40 \times 15$ $\mathrm{cm}^{2}+$ NPK $75 \%+$ Vermicompost $25 \%$ ) and it was significantly superior over all the treatments. The minimum number of florets per spike (11.02) was observed in the treatment $T_{1}\left(30 \times 30 \mathrm{~cm}^{2}+200: 200: 200 \mathrm{~kg}\right.$ NPK) The superiority of treatment $T_{12}$ for number of florets over the other treatments may be due to the availability of organic and inorganic fertilizers and other essential nutrients for longer period at optimum level resulting in more number of florets per spike. This result is in close agreement with the findings of Ahmed et al., (2004).

The data presented in Table 2 envisaged that the Treatment $\mathrm{T}_{12}\left(40 \times 15 \mathrm{~cm}^{2}+\right.$ NPK $75 \%+$ Vermicompost 25\%) had the longest vase (13.13days) in $\left.\mathrm{Al}_{2} \mathrm{SO}_{4}\right)_{2}$ - 200ppm where as the minimum vase life 9.96 days in distilled water was obtained in treatment $\mathrm{T}_{1}(30 \mathrm{X} 30$ $\left.\mathrm{cm}^{2}+200: 200: 200 \mathrm{~kg} \mathrm{NPK}\right)$. The maximum vase life in treatment $T_{12}$ may be due to the positive effect of inorganic nitrogen in combination with organic manure Vermicompost on the vase life and also due to more accumulation of carbohydrate which increased the vase life of cut spikes. Similar findings are reported by Narendra et al., (2013).

The data presented in Table 3 envisaged that the maximum diameter of corm was noticed in the treatment $\mathrm{T}_{11} 40 \times 15 \mathrm{~cm}^{2}+75 \% \mathrm{NPK}+$ $25 \%$ Goat manure) $(5.66 \mathrm{~cm})$ whereas the minimum diameter of corm was obtained in the treatment $T_{1}\left(30 \times 30 \mathrm{~cm}^{2}+200: 200: 200\right.$ $\mathrm{kg}$ NPK) $(3.35 \mathrm{~cm})$. It may be due to Goat manure and other essential nutrient NPK and proper spacing was regularly available to the plant at critical stage of growth and development of corm which, in turn, resulted in faster and better development of corm. This result is in close agreement with the findings of Varu et al., (1994).

The data presented in Table 3 envisaged that the maximum weight per corm was recorded in the treatment $\mathrm{T}_{11}\left(40 \times 15 \mathrm{~cm}^{2}+75 \% \mathrm{NPK}+\right.$ $25 \%$ Goat manure) (66.69g.) whereas minimum weight per corm was found in the treatment $\mathrm{T}_{1}\left(30\right.$ X $30 \mathrm{~cm}^{2}+200: 200: 200 \mathrm{~kg}$ NPK) (32.43g). Similar result was obtained by Varu et al., (1994).

The data presented in Table 3 envisaged that the no. of spike per plant was recorded maximum in Treatment $\mathrm{T}_{8}\left(30 \times 15 \mathrm{~cm}^{2}+\right.$ $75 \%$ NPK $+25 \%$ Vermicompost) (1.29) and spike was obtained minimum in Treatment $\mathrm{T}_{1}$ (30 X $\left.30 \mathrm{~cm}^{2}+200: 200: 200 \mathrm{~kg} \mathrm{NPK}\right)$ (1.00). This result is in close agreement with the findings of Sud et al., (2010).

The data presented in Table 3 envisaged that the highest no. Of corm was obtained in treatment $\mathrm{T}_{8}\left(30 \times 15 \mathrm{~cm}^{2}+75 \% \mathrm{NPK}+25 \%\right.$ Vermicompost) (1.28) and minimum no. of corm was found in treatment $T_{1}\left(30 \times 30 \mathrm{~cm}^{2}\right.$ + 200:200:200 kg NPK) (1.00). It may be due to higher germination percentage of corm with the application of inorganic fertilizer in combination with Vermicompost and proper spacing $\left(30 \times 15 \mathrm{~cm}^{2}\right)$. This result is in close agreement with the findings of Sud et al., (2010).

The data presented in Table 3 envisaged that the highest yield of spike per hectare was obtained in the treatment $\mathrm{T}_{8}\left(30 \times 15 \mathrm{~cm}^{2}+\right.$ $75 \%$ NPK $+25 \%$ Vermicompost $)(2,60,000)$ and minimum spike yield was recorded in treatment $\mathrm{T}_{1}\left(30\right.$ X $30 \mathrm{~cm}^{2}+200: 200: 200 \mathrm{~kg}$ 
NPK) $(1,11,111)$ The greater spike yield per hectare might be due to an optimum combination of fertilizers and manures with short spacing. The similar increase in flower yield due to increase in number of sprouts and spike length. Similar findings are reported by Radhika et al., (2010).

The data presented in Table 3 envisaged that the maximum yield of corms 2,67407corms/ha. recorded in the treatment $\mathrm{T}_{8}\left(30 \times 15 \mathrm{~cm}^{2}+75 \% \mathrm{NPK}+25 \%\right.$ Vermicompost) which was significantly superior over all the treatment. The minimum yield of corms $(1,11111)$ corms/ha was found in the treatment $\mathrm{T}_{1}\left(30 \mathrm{X} 30 \mathrm{~cm}^{2}+\right.$ 200:200:200 kg NPK). Increase in yield with treatment $\mathrm{T}_{8}$ may be due to assimilation of carbohydrate and protein resulting in better vegetative growth of plant. This probably helped in better tuberization of corm and increase their weight and size may be due to higher germination percentage of corm with the application of inorganic fertilizer in combination with Vermicompost and proper spacing $\left(30 \times 15 \mathrm{~cm}^{2}\right)$. This result is in close agreement with the findings of Hassandokht and Kashi (2000).

The highest benefit cost ratio was found in the treatment $\mathrm{T}_{12}\left(40 \times 15 \mathrm{~cm}^{2}+\right.$ NPK $75 \%+$ Vermicompost 25\%) (3.50:1) whereas the lowest benefit cost ratio was recorded in the treatment $\mathrm{T}_{1}\left(30 \times 30 \mathrm{~cm}^{2}+200: 200: 200 \mathrm{~kg}\right.$ NPK) (2.77:1).

Table.1 Combined effect of planting density and organic and inorganic fertilizer on growth characteristics of gladiolus

\begin{tabular}{|c|c|c|c|c|c|}
\hline \multirow[b]{2}{*}{ Treatments } & \multicolumn{5}{|c|}{ Growth Characteristics } \\
\hline & $\begin{array}{l}\text { Days to } 50 \% \\
\text { sprouting }\end{array}$ & $\begin{array}{c}\text { Number of } \\
\text { sprouts per corm }\end{array}$ & $\begin{array}{c}\text { Plant height } \\
\text { (cm) }\end{array}$ & $\begin{array}{c}\text { Number of leaves } \\
\text { per plant }\end{array}$ & $\begin{array}{l}\text { Width of the leaf } \\
(\mathrm{cm})\end{array}$ \\
\hline$S_{1} F_{1}\left(T_{1}\right)$ & 6.46 & 1 & 117.66 & 6.86 & 3.05 \\
\hline $\mathbf{S}_{1} \mathbf{F}_{2}\left(\mathbf{T}_{2}\right)$ & 5.6 & 1.13 & 120.8 & 7.46 & 3.28 \\
\hline $\mathbf{S}_{1} \mathbf{F}_{3}\left(\mathbf{T}_{3}\right)$ & 6.06 & 1.16 & 119.46 & 7.2 & 3.42 \\
\hline$S_{1} F_{4}\left(T_{4}\right)$ & 5.53 & 1.26 & 119 & 7.33 & 3.42 \\
\hline $\mathbf{S}_{2} \mathbf{F}_{1}\left(\mathbf{T}_{5}\right)$ & 5.73 & 1.33 & 121.93 & 8.4 & 3.42 \\
\hline$S_{2} F_{2}\left(T_{6}\right)$ & 5.46 & 1.26 & 118.2 & 7.4 & 3.40 \\
\hline $\mathbf{S}_{2} \mathbf{F}_{3}\left(\mathbf{T}_{7}\right)$ & 6.26 & 1.43 & 123.2 & 9.7 & 3.63 \\
\hline$S_{2} F_{4}\left(T_{8}\right)$ & 5.33 & 1.46 & 119.86 & 7.86 & 3.38 \\
\hline$S_{3} F_{1}\left(T_{9}\right)$ & 5.73 & 1.26 & 118.11 & 7.6 & 3.60 \\
\hline$S_{3} F_{2}\left(T_{10}\right)$ & 5.8 & 1.26 & 120.86 & 7.73 & 3.69 \\
\hline$S_{3} F_{3}\left(T_{11}\right)$ & 5.4 & 1.4 & 119.75 & 7.46 & 3.39 \\
\hline$S_{3} F_{4}\left(T_{12}\right)$ & 5.66 & 1.26 & 124.13 & 10.4 & 3.47 \\
\hline
\end{tabular}

$\mathrm{S}_{1:} 30 \mathrm{~cm} \times 30 \mathrm{~cm}, \mathrm{~S}_{2}: 30 \mathrm{~cm} \times 15 \mathrm{~cm} \quad, \mathrm{~S}_{3:} 40 \mathrm{~cm} \times 15 \mathrm{~cm}, \mathrm{~F}_{1:} 200: 200: 200 \mathrm{~kg} / \mathrm{h}, \mathrm{F}_{2}$ : NPK 75\% + FYM 25\%, $\mathrm{F}_{3:} \mathrm{NPK} 75 \%+\mathrm{GM}$ $25 \%, \mathrm{~F}_{4}: \mathrm{NPK} 75 \%+\mathrm{VC} 25 \%$ 
Table.2 Combined effect of planting density and organic and inorganic fertilizer on floral characteristics of gladiolus

\begin{tabular}{|c|c|c|c|c|c|c|c|}
\hline \multirow[b]{2}{*}{ Treatments } & \multicolumn{7}{|c|}{ Floral Characteristics } \\
\hline & $\begin{array}{c}\text { Days to Spike } \\
\text { initiation }\end{array}$ & $\begin{array}{c}\text { Opening } \\
\text { Of first } \\
\text { floret } \\
\text { (days) }\end{array}$ & $\begin{array}{l}\text { Spike } \\
\text { length } \\
\text { (cm) }\end{array}$ & $\begin{array}{c}\text { Number of } \\
\text { florets per } \\
\text { spike }\end{array}$ & $\begin{array}{c}\text { Longevity of } \\
\text { first floret } \\
\text { In } \mathrm{Al}_{2}\left(\mathrm{SO}_{4}\right)_{3} \\
\text { (days) }\end{array}$ & $\begin{array}{c}\text { Vase Life of } \\
\text { Spikes In } \\
\mathrm{Al}_{2}\left(\mathrm{SO}_{4}\right)_{3}\end{array}$ & $\begin{array}{c}\text { No. of spikes per } \\
\text { plant }\end{array}$ \\
\hline$S_{1} F_{1}\left(T_{1}\right)$ & 77.46 & 94.35 & 60.81 & 11.02 & 4.11 & 10.66 & 1 \\
\hline$S_{1} F_{2}\left(T_{2}\right)$ & 70.19 & 83.73 & 80.78 & 11.87 & 4.86 & 11.66 & 1.15 \\
\hline$S_{1} F_{3}\left(T_{3}\right)$ & 75.39 & 84.66 & 64.83 & 11.57 & 4.45 & 11 & 1.11 \\
\hline $\mathbf{S}_{1} \mathbf{F}_{4}\left(\mathbf{T}_{4}\right)$ & 72.3 & 85.24 & 72.75 & 14.45 & 4.90 & 11.33 & 1.07 \\
\hline$S_{2} F_{1}\left(T_{5}\right)$ & 65.57 & 89.24 & 65.83 & 13.07 & 4.53 & 12 & 1.00 \\
\hline$S_{2} F_{2}\left(T_{6}\right)$ & 72.53 & 89.34 & 99.35 & 12.27 & 4.49 & 12 & 1.15 \\
\hline$S_{2} F_{3}\left(T_{7}\right)$ & 77.30 & 90.01 & 100.39 & 13.34 & 5.44 & 13 & 1.17 \\
\hline$S_{2} F_{4}\left(T_{8}\right)$ & 67.44 & 88.12 & 87.32 & 14.35 & 5.21 & 12 & 1.29 \\
\hline$S_{3} F_{1}\left(T_{9}\right)$ & 76.35 & 89.66 & 87.40 & 12.44 & 4.86 & 12.33 & 1.01 \\
\hline$S_{3} F_{2}\left(T_{10}\right)$ & 67.39 & 80.77 & 67.09 & 12.01 & 5.13 & 12 & 1.03 \\
\hline $\mathbf{S}_{3} \mathbf{F}_{3}\left(\mathbf{T}_{11}\right)$ & 65.43 & 88.59 & 86.63 & 12.07 & 4.68 & 11.66 & 1.15 \\
\hline $\mathbf{S}_{3} \mathbf{F}_{4}\left(\mathbf{T}_{12}\right)$ & 64.40 & 80.33 & 101.34 & 16 & 5.74 & 13.13 & 1.08 \\
\hline
\end{tabular}

$\mathrm{S}_{1:} 30 \mathrm{~cm} \times 30 \mathrm{~cm}, \mathrm{~S}_{2}: 30 \mathrm{~cm} \times 15 \mathrm{~cm}, \mathrm{~S}_{3}: 40 \mathrm{~cm} \times 15 \mathrm{~cm}, \mathrm{~F}_{1:}$ 200:200:200 kg/h, F 2 NPK 75\% + FYM 25\%, F 3 NPK 75\% + GM 25\%, F $:$ NPK 75\% + VC 25\% 
Table.3 Combined effect of planting density and organic and inorganic fertilizer on yield characteristics of gladiolus

\begin{tabular}{|c|c|c|c|c|c|c|}
\hline \multirow[b]{2}{*}{ Treatments } & \multicolumn{6}{|c|}{ YieldCharacteristics } \\
\hline & $\begin{array}{l}\text { Diameter of } \\
\text { corm }(\mathbf{c m})\end{array}$ & $\begin{array}{l}\text { Weight of } \\
\text { Corms (g) }\end{array}$ & $\begin{array}{c}\text { No. of Spike per } \\
\text { plant }\end{array}$ & $\begin{array}{c}\text { Number of } \\
\text { Corms per } \\
\text { plant }\end{array}$ & $\begin{array}{c}\text { Spike yield per } \\
\text { hectare } \\
\text { ('000 Hectare) }\end{array}$ & $\begin{array}{c}\text { Corm yield per } \\
\text { hectare }\end{array}$ \\
\hline$S_{1} F_{1}\left(T_{1}\right)$ & 3.35 & 32.43 & 1 & 1.01 & 111.111 & 111111 \\
\hline$S_{1} F_{2}\left(T_{2}\right)$ & 4.87 & 54.17 & 1.15 & 1.06 & 128.148 & 211481 \\
\hline$S_{1} F_{3}\left(T_{3}\right)$ & 5.40 & 58.03 & 1.11 & 1.15 & 124.074 & 139629 \\
\hline$S_{1} F_{4}\left(T_{4}\right)$ & 5.41 & 60.63 & 1.07 & 1.07 & 120.37 & 124074 \\
\hline $\mathbf{S}_{2} \mathbf{F}_{1}\left(\mathbf{T}_{5}\right)$ & 4.38 & 50.19 & 1.00 & 1.00 & 223.703 & 223703 \\
\hline$S_{2} F_{2}\left(T_{6}\right)$ & 4.55 & 56.98 & 1.15 & 1.15 & 240 & 232592 \\
\hline $\mathbf{S}_{2} \mathbf{F}_{3}\left(\mathbf{T}_{7}\right)$ & 5.59 & 63.55 & 1.17 & 1.17 & 255.555 & 255555 \\
\hline$S_{2} F_{4}\left(T_{8}\right)$ & 3.54 & 42.98 & 1.29 & 1.28 & 260.000 & 267407 \\
\hline$S_{3} F_{1}\left(T_{9}\right)$ & 4.54 & 53.68 & 1.01 & 1 & 168.333 & 168333 \\
\hline$S_{3} F_{2}\left(T_{10}\right)$ & 3.85 & 38.92 & 1.03 & 1.15 & 172.777 & 177777 \\
\hline $\mathbf{S}_{3} \mathbf{F}_{3}\left(\mathbf{T}_{11}\right)$ & 5.65 & 66.69 & 1.15 & 1.11 & 191.666 & 191666 \\
\hline $\mathbf{S}_{3} \mathbf{F}_{4}\left(\mathbf{T}_{12}\right)$ & 4.51 & 52.70 & 1.08 & 1.07 & 239.999 & 213333 \\
\hline
\end{tabular}

$\mathrm{S}_{1}: 30 \mathrm{~cm} \times 30 \mathrm{~cm}, \mathrm{~S}_{2}: 30 \mathrm{~cm} \times 15 \mathrm{~cm}, \mathrm{~S}_{3:}: 40 \mathrm{~cm} \times 15 \mathrm{~cm}, \mathrm{~F}_{1}: 200: 200: 200 \mathrm{~kg} / \mathrm{h}, \mathrm{F}_{2}: \mathrm{NPK} 75 \%+\mathrm{FYM} 25 \%, \mathrm{~F}_{3}: \mathrm{NPK} 75 \%+\mathrm{GM} 25 \%, \mathrm{~F}_{4}: \mathrm{NPK} 75 \%+\mathrm{VC} 25 \%$ 
On the basis of this research, treatment $\mathrm{T}_{12}$ (40x15 $\mathrm{cm}^{2}+$ NPK $75 \%+$ Vermicompost $25 \%)$ performed higher in number of leaves per plant, height of the plant $(\mathrm{cm})$,days to spike emergence, length of the spike, number of florets per spikes, vase life of cut spikes (days),days to opening of first florets, longevity of first florets(days). Whereas the earliest $50 \%$ sprouting, number of sprouts per mother corm, the yield of corms per hectare, spike yield per hectare, was recorded highest in Treatment $\mathrm{T}_{8}\left(30 \times 15 \mathrm{~cm}^{2}+75 \% \mathrm{NPK}+\right.$ $25 \%$ Vermicompost) and the treatment $\mathrm{T}_{11}$ $\left(40 \times 15 \mathrm{~cm}^{2}+75 \% \mathrm{NPK}+25 \%\right.$ Goat manure $)$ performed best in Diameter of corms $(\mathrm{cm})$ and Weight of corms (g). These characters may affect significantly due to different combination of spacing and source of fertilizer. However, since this is based on one season experiment, further trials may be needed to substantiate the results.

\section{References}

Ahmed, M., Khan, M., F., Hamid, A. and Hussain, A. 2004. Effect of urea, DAP and FYM on growth and flowering of dahlia. International Journal of Agriculture and Biology, 6(2): 393395.

Bisen, A.L. and Barholia, A., K. 1990. Note on response of potato to methods and nitrogen application. Indian Journal of Horticulture, 47(4): 424- 426.

Gupta, P., Rajwal, N, Dhaka, V., K. and Rajwal, D. 2008. Effect of different levels of vermicompost, NPK and FYM on performance of gladiolus (Gladiolus grandiflorus L.) cv. happy end. Asian Journal of Horticulture, 3(1): 142-143.

Hassandokht, M.R. and Kashi, A. 2000.Effects of farmyard manure and nitrogen application on the quantity and quality of potato crop. Seed and Plant Journal, 15(4): 323-330.
Kumar, R. (2005). Effect of integrated use of chemical fertilizers, biofertilizers and biostimulants in gladiolus (Gladiolus grandiflorus L.) cv. Sancerre. Progressive Horticulture Vol. 43(1): 149-152,

Narendra, C., Swaroop, K., Janakiram, T., Biswas, D.R. and Singh, G. (2013), Effect of integrated nutrient management on vegetative growth and flowering characters of gladiolus. Indian J. Hort. 70(1), March 2013: 156-159.

Radhika, M., Patel, H. C., Nayee, D.D., and Sitapara, H.H. (2010), Effect of integrated nutrient management on growth and yield of African marigold (Tagetes erecta L.) cv. 'Local' under middle Gujarat agro-climatic conditions. Asian Journal of Horticulture; 2010.5(2):347-349.

Shankar, D. 2001. Studies on response of NPK and FYM alone, and in combination on production of gladiolus corms through cormels. M.Sc. (Ag) Thesis submitted to Indira Gandhi Krishi Vishwavidyalaya, Raipur, Chattisgarh, p. 62.

Singh, K.P. 1998. Response of graded level and split doses of nitrogen application in multiplication of gladiolus corm through cormels, Advances in Plant Science, 11(2): 305- 307.

Singh, S.P. and Singh, R., P. 1971. Response of potato (Solanum tuberosum L.) variety Kufri Sindhuri to farm yard manure and fertilizer nitrogen. Journal of Plant Science, 3: 108- 112.

Singh, A., K. and Bijimol, G. (2000). Effect of spacing and nitrogen on gladiolus. J. Ornametal Hort., New Series, 6(1): 73-75.

Sud, K.C., Grewal, J.S. and Trehan, S.P. 2010. Effect of farm yard manure and nitrogen on potato (Solanum tuberosum) production and 
phosphorus and potassium availability in hill soils of Shimla. Indian Journal of Agricultural Sciences, 60(8): 529532.

Varu, D.K., Vhora, P.H. and Kikani, K.P. 1994. Effect of organic and inorganic fertilizers on onion. Gujarat
Agricultural University Research Journal 14 (1): 128-131.

Widjajanto, D.D. and Widodo, 1982.The effect of farmyard manure and nitrogen fertilizer on growth and production of potatoes. Bulletin Pen.

\section{How to cite this article:}

Santosh Kumar Beck, Manoj Kumar Beck and Premanshu Agrawal. 2019. Analyzing Different Spacing and Fertilizer Applications Interaction Effect on Growth, Flowering and Yield of Gladiolus (Gladiolus grandiflorus L.). Int.J.Curr.Microbiol.App.Sci. 8(04): 707-715.

doi: https://doi.org/10.20546/ijcmas.2019.804.076 